\title{
PREZENTACJA CEN DÓBR KONSUMPCYJNYCH ORAZ DYNAMIKI ICH ZMIAN ZA POMOCA SKIEROWANYCH LICZB ROZMYTYCH $^{2}$
}

\begin{abstract}
Streszczenie
W pracy krótko przedstawiono model skierowanych liczb rozmytych $(O F N)$. Następnie liczby te wykorzystano do opisu i graficznej prezentacji cen dóbr konsumpcyjnych (bieżącej i bazowej) oraz dynamiki ich zmian. Opis cen dóbr za pomocą OFN pozwala na łatwą i szybką agregację danych, a także budowę koszyka dóbr. Z kolei, ilustracja graficzna cen dóbr w postaci skierowanych liczb rozmytych umożliwia prosty odbiór kilku informacji jednocześnie, takich jak: cena bieżąca, cena bazowa, kierunek czy dynamika zmiany ceny. Daje to konsumentowi możliwość łatwego uporządkowania dóbr pod względem korzystności zmiany ceny, tzn. od najkorzystniejszej, czyli takiej, gdy cena dobra spadła w największym stopniu, do najmniej korzystnej, czyli takiej, gdy cena wzrosła w stopniu największym.
\end{abstract}

Słowa kluczowe: skierowane liczby rozmyte, ceny dóbr konsumpcyjnych, dynamika zmiany cen, koszyk dóbr

\section{PRESENTATION OF CONSUMER GOODS PRICES AND THEIR DYNAMICS: ORDERED FUZZY NUMBERS ANALYSIS}

\section{Summary}

First, the paper briefly discusses the model of ordered fuzzy numbers. Next, the method is used for the description and graphic presentation of consumer goods prices (current and base) and of the dynamics of price change. The description of goods prices with the use of OFN facilitates the aggregation of data and building of a basket of goods. What is more, the graphic illustration of goods prices in the form of OFN enables simple reception of information, such as the current price, the base price, the direction of price change, or the dynamics of price change. It gives the consumer an excellent opportunity to arrange goods in terms of benefit, starting with the most profitable change when the price drops the most and finishing with the least profitable one when the price increases the most.

Key words: ordered fuzzy numbers, consumer goods prices, dynamics of price change, basket of goods

\footnotetext{
${ }^{1}$ dr Dariusz Kacprzak - Wydział Informatyki, Politechnika Białostocka; email: d.kacprzak@pb.edu.pl.

2 Praca wykonana w ramach realizacji pracy statutowej S/WI/2/2011.
} 


\section{Wstęp}

Zaczynając od rządów przez przedsiębiorstwa, gospodarstwa domowe, a kończąc na pojedynczym konsumencie, wszyscy są zainteresowani kształtowaniem się cen w gospodarce. Inflacja sprawia, że siła nabywcza pieniądza konsumentów maleje i są oni w stanie kupić mniej dóbr w danym okresie w porównaniu z okresem bazowym czy poprzednim (przy stałych dochodach). Powoduje to sytuację, w której zakup towarów i usług drożejących jest ograniczany lub też są one zastępowane substytutami, których ceny nie wzrosły lub wzrosły w stopniu mniejszym.

W mass mediach czy na stronach GUS-u można znaleźć informację, o tym że inflacja w Polsce w 2012 roku (w stosunku do roku 2011) wyniosła 3,7\%. Oznacza to wzrost przeciętnej ceny dóbr (określonego koszyka) w 2012 roku w stosunku do roku 2011. Jednak konsumenta interesują również ceny poszczególnych dóbr. Istotne są bowiem informacje o tym, których towarów i usług ceny wzrosły, których się nie zmieniły, a których spadły. Wiedza ta ma decydujący wpływ na decyzje konsumenta w trakcie nabywania dóbr.

Ceny dóbr można opisać za pomocą liczb rzeczywistych i zestawić w tabeli, co pozwala na ich porównywanie. Mimo to, przy dużej liczbie towarów, właściwa interpretacja informacji o kształtowaniu się cen może być kłopotliwa. W takich sytuacjach wygodne staje się posługiwanie różnymi narzędziami, m.in.: wykresami, średnimi, wskaźnikami, które ułatwiaja przekaz i wykorzystanie informacji.

Do prezentacji informacji o cenach dóbr i dynamice ich zmian można użyć skierowanych liczb rozmytych. Pozwalaja one w przejrzysty i czytelny sposób prezentować kilka informacji jednocześnie. Ponadto, określone na nich działania arytmetyczne umożliwiaja łatwą agregację informacji.

\section{Skierowane liczby rozmyte}

Model skierowanych liczb rozmytych (Ordered Fuz:y Numbers - OFN) został zaproponowany w pracach Kosińskiego i Prokopowicza [Kosiński i in., 2002a; Kosiński i inni, 2002b; Kosiński i inni, 2003; Kosiński, Prokopowicz, 2004]. Poniższa prezentacja OFN jest oparta na pracach Kosińskiego i Kacprzaka [Kosiński i in., 2009; Kacprzak, 2010; Kacprzak, 2012a; Kacprzak, 2012b].

Skierowaną liczbą rozmytą $A$ nazywamy uporządkowana parę funkcji:

$$
A=\left(f_{A}, g_{A}\right) \text {, }
$$

gdzie obie funkcje są ciagłe oraz $f_{A}, g_{A}:[0,1] \rightarrow R$. Poszczególne składowe skierowanej liczby rozmytej $A$ nazywamy: $f_{A}$ i jest to część wznosząca $(U P)$, natomiast $g_{A}$ jest częścia opadająca $(D O W N)$. Z ciagłości obu funkcji wynika, że ich obrazy są ograniczonymi przedziałami odpowiednio: $U P_{A}=\left(l_{A}, 1_{A}^{-}\right)$oraz $D O W N_{A}=\left(1_{A}^{+}, p_{A}\right)$, gdzie $l_{A}=$ $f_{A}(0), 1_{A}^{-}=f_{A}(1), 1_{A}^{+}=g_{A}(1), p_{A}=g_{A}(0)$. Rysunek 1a jest ilustracja graficzna skierowanej liczby rozmytej $A$, gdzie $y$ jest argumentem funkcji $f_{A}$ i $g_{A}$, zaś $x$ wartością tych funkcji. Jeżeli funkcje $f_{A}$ i $g_{A}$ są ściśle monotoniczne, to istnieją do nich 
funkcje odwrotne $f_{A}^{-1}$ i $g_{A}^{-1}$, określone na odpowiednich przedziałach $U P_{A}$ i $D O W N_{A}$. Na przedziale $\left[1_{A}^{-}, 1_{A}^{+}\right]$(może być on zbiorem jednoelementowym) dołączamy funkcję stałą (CONST) równą 1 . Dzięki temu możemy zdefiniować funkcję przynależności $\mu_{A}$ skierowanej liczby rozmytej $A$ w następujący sposób (rysunek 1b):

$$
\mu_{A}(x)=\left\{\begin{array}{c}
0 \text { gdy } x \notin\left[l_{A}, p_{A}\right] \\
f_{A}^{-1}(x) \text { gdy } x \in U P_{A} \\
1 \text { gdy } x \in\left[1_{A}^{-}, 1_{A}^{+}\right] \\
g_{A}^{-1}(x) \text { gdy } x \in D O W N_{A}
\end{array} .\right.
$$

Skierowane liczby rozmyte nawiązują do klasycznych liczb rozmytych, jednak sa wyposażone w dodatkową własność zaznaczoną strzałka - skierowanie (rysunek 1c). Strzałka określa kolejność odwróconych funkcji $f_{A}^{-1}$ i $g_{A}^{-1}$ skierowanej liczby rozmytej $A$ (równanie 1.).

Szczególnym przypadkiem skierowanych liczb rozmytych są liczby rzeczywiste. W modelu OFN są one utożsamiane z parą funkcji stałych. Liczba rzeczywista $r(r \in R)$ w postaci skierowanej liczby rozmytej ma postać $r=\left(r^{*}, r^{*}\right)$, gdzie $r^{*}(y)=r$ dla $y \in[0,1]$.

Podstawowe działania arytmetyczne, czyli dodawanie $(+)$, odejmowanie $(-)$, mnożenie $(\cdot)$ i dzielenie $(/)$, na skierowanych liczbach rozmytych są określone następująco. Niech $A=\left(f_{A}, g_{A}\right), B=\left(f_{B}, g_{B}\right)$ będą skierowanymi liczbami rozmytymi. Wówczas liczba $C=\left(f_{C}, g_{C}\right)$ jest wynikiem działania $(*)$ na skierowanych liczbach rozmytych $A$ i $B$ $(C=A * B)$, jeżeli:

$$
\forall y \in[0,1]\left[f_{A}(y) * f_{B}(y)=f_{C}(y) \text { i } g_{A}(y) * g_{B}(y)=g_{C}(y)\right] .
$$

Działanie (*) oznacza jedno z podstawowych działań arytmetycznych. W przypadku dzielenia dodatkowo musi być spełniony warunek, że $\forall y \in[0,1] f_{B}(y) \neq 0$ i $g_{B}(y) \neq 0$. Zbiór skierowanych liczb rozmytych z tak określonymi działaniami ma strukturę przestrzeni liniowo-topologicznej [Kosiński, Prokopowicz, 2004].

W określeniu funkcji przynależności skierowanej liczby rozmytej (równanie 2.) pojawiają się cztery parametry: $l_{A}, 1_{A}^{-}, 1_{A}^{+}, p_{A}$, które w sposób jednoznaczny opisuja tę liczbę. Wynika stąd, że skierowaną liczbę rozmytą można reprezentować za pomocą tych czterech elementów (rysunek 2.):

$$
A=\left(l_{A} 1_{A}^{-} 1_{A}^{+} p_{A}\right) \text {. }
$$

Taka reprezentacja OFN umożliwia szybkie wykonywanie działań arytmetycznych. W dalszej części pracy wykorzystamy dodawanie skierowanych liczb rozmytych oraz mnożenie skierowanej liczby rozmytej przez liczbę rzeczywista. Z tego względu prezentację działań na OFN w postaci równania (4) ograniczymy do tych dwóch. Niech $A=\left(l_{A} 1_{A}^{-} 1_{A}^{+} p_{A}\right)$ i $B=\left(\begin{array}{lll}l_{B} & 1_{B}^{-} & 1_{B}^{+} p_{B}\end{array}\right)$ będą skierowanymi liczbami rozmytymi i niech $\alpha \in R$, wówczas:

$$
\begin{array}{ll}
- & A+B=\left(l_{A}+l_{B} 1_{A}^{-}+1_{B}^{-} 1_{A}^{+}+1_{B}^{+} p_{A}+p_{B}\right), \\
- & \alpha A=\left(\alpha l_{A} \alpha 1_{A}^{-} \alpha 1_{A}^{+} \alpha p_{A}\right) .
\end{array}
$$


RYSUNEK 1.

a) Przykładowa skierowana liczba rozmyta, b) skierowana liczba rozmyta przedstawiona w sposób nawiązujący do liczb rozmytych w klasycznym podejściu, c) strzałka przedstawiająca kolejność odwróconych funkcji i orientację skierowanej liczby rozmytej

a)

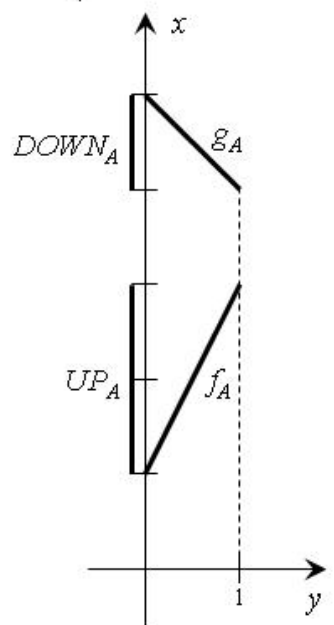

b)

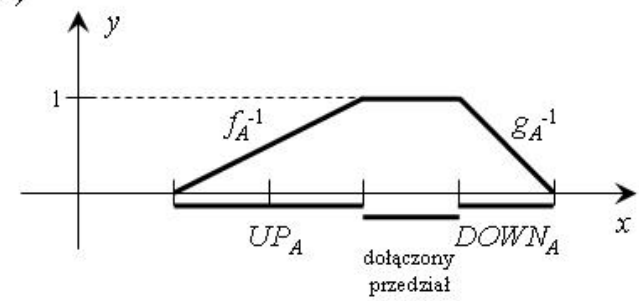

c)

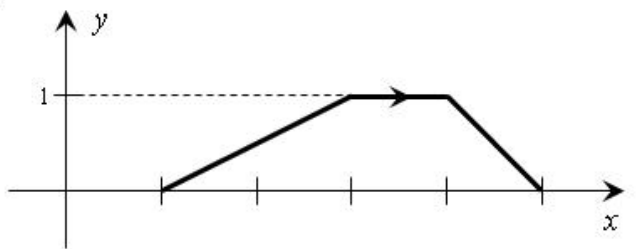

Źródło: [Kosiński i in., 2009].

RYSUNEK 2.

\section{Przykładowa $O F N$ wraz z charakterystycznymi punktami}

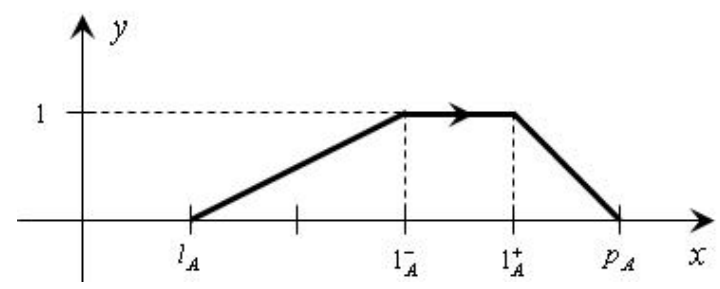

Źródło: [Kacprzak, 2010].

Nośnikiem liczby rozmytej $A$ nazywamy zbiór $\operatorname{supp} A=\left\{x \in X: \mu_{A}(x)>0\right\}$. Jadrem liczby rozmytej $A$ jest zbiór $\operatorname{ker} A=\left\{x \in X: \mu_{A}(x)=1\right\}$. W przypadku skierowanej liczby rozmytej $A=\left(l_{A} 1_{A}^{-} 1_{A}^{+} p_{A}\right)$, (rysunek 2.) $\operatorname{supp} A=\left(l_{A}, p_{A}\right)$ oraz $\operatorname{ker} A=\left[1_{A}^{-}, 1_{A}^{+}\right]$. Możemy również określić szerokość nośnika i jądra jako $|\operatorname{supp} A|=\left|l_{A}-p_{A}\right| \mathrm{i}|\operatorname{ker} A|=\left|1_{A}^{-}-1_{A}^{+}\right|$.

W kolejnej części wykorzystamy trójkątne, symetryczne skierowane liczby rozmyte do prezentacji cen dóbr konsumpcyjnych oraz dynamiki ich zmian. Liczby trójkątne to takie, w których funkcje składowe $f_{A}$ i $g_{A}$ są funkcjami liniowymi, a jądro 
jest zbiorem jednoelementowym. Symetria liczby oznacza, że funkcje składowe $f_{A}$ i $g_{A}$ są symetryczne względem prostej $x=\operatorname{ker} A$ (rysunek 3.). Zapisane zgodnie z równaniem (4) liczby te mają postać:

$$
A=\left(a \frac{a+b}{2} \frac{a+b}{2} b\right) .
$$

\section{RYSUNEK 3.}

\section{Przykładowa $O F N$ trójkątna, symetryczna}

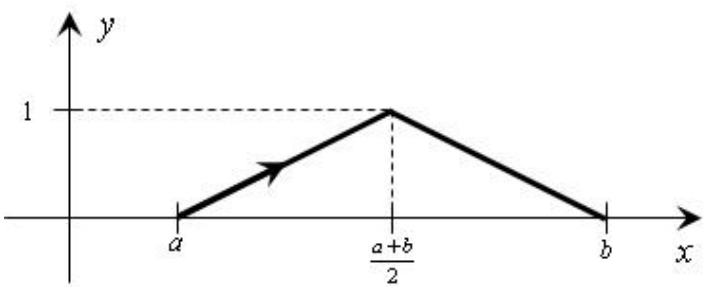

Źródło: opracowanie własne.

\section{Prezentacja cen dóbr konsumpcyjnych oraz dynamiki ich zmian za pomo- cą skierowanych liczb rozmytych}

Załóżmy, że konsument w kolejnych latach $t(t=0,1,2, \ldots, m)$ nabywa określony koszyk dóbr złożony z $N$ towarów w ilościach $q_{i}$ (zakładamy, że ilość dóbr w koszyku w kolejnych latach nie ulega zmianie) po cenach $p_{t i}(i=1,2,3, \ldots, N)$. Konsumenta interesuje, jak zmieniają się ceny poszczególnych dóbr oraz wartość koszyka w roku $t \mathrm{w}$ stosunku do odpowiednich cen i wartości z okresu bazowego $(t=0)$. Aby zobrazować te informacje wykorzystamy skierowane liczby rozmyte. Pozwalaja one na jednoczesne obrazowanie ceny dobra nabywanego przez konsumenta w badanym okresie, a także w okresie bazowym. Ceny $i$-tego dobra opisujemy wówczas skierowaną liczbą rozmytą $p_{i}$ postaci:

$$
p_{i}=\left(p_{0 i} \frac{p_{0 i}+p_{t i}}{2} \frac{p_{0 i}+p_{t i}}{2} p_{t i}\right),
$$

gdzie $p_{0 i}$ oznacza cenę w okresie bazowym, natomiast $p_{t i}$ cenę w badanym okresie $t$. Możemy wyróżnić trzy przypadki:

a) cena $i$-tego dobra w badanym okresie wzrosła $\mathrm{w}$ stosunku do ceny $\mathrm{z}$ okresu bazowego, czyli $p_{0 i}<p_{t i}-$ rysunek $4 a$;

b) cena $i$-tego dobra w badanym okresie nie zmieniła się w stosunku do okresu bazowego, czyli $p_{0 i}=p_{t i}-$ rysunek $4 \mathrm{~b}$;

c) cena $i$-tego dobra w badanym okresie zmalała w stosunku do okresu bazowego, czyli $p_{0 i}>p_{t i}-$ rysunek $4 \mathrm{c}$.

Jak widać na rysunku 4., kluczową własnością OFN, która pozwala ocenić kształtowanie się bieżącej ceny dobra w odniesieniu do ceny bazowej, jest skierowanie. Ponadto, z szerokości nośnika możemy odczytać wielkość zmiany ceny. 
Jednak wielkość zmiany ceny dobra może być niewłaściwie zinterpretowana i myląca dla konsumenta. Wynika to z faktu, że „odczuwalność” przez niego na przykład wzrostu ceny dobra o 1 jednostkę pieniężną (j.p.) może być inna dla różnych cen bazowych. Jeżeli cena dobra z poziomu 100 j.p. wzrosła do 101 j.p. (czyli o 1\%), to taka zmiana może być dla konsumenta nieistotna, ale jeśli cena wzrosła z 2 j.p. do 3 j.p. (czyli o 50\%), to ta zmiana może być bardzo dotkliwa. Z tego względu, aby informacja o cenach była pełniejsza, do wykresów widocznych na rysunku 4. dołączymy wykresy obrazujące dynamikę zmiany ceny (zmianę ceny w okresie badanym w stosunku do okresu bazowego). Dynamika zmiany ceny $i$-tego dobra będzie reprezentowana skierowaną liczbą rozmyta $p p_{i}$ postaci:

$$
p p_{i}=\frac{1}{p_{0 i}} \cdot p_{i}=\frac{1}{p_{0 i}} \cdot\left(p_{0 i} \frac{p_{0 i}+p_{t i}}{2} \frac{p_{0 i}+p_{t i}}{2} p_{t i}\right)=\left(1 \frac{p_{0 i}+p_{t i}}{2 p_{0 i}} \frac{p_{0 i}+p_{t i}}{2 p_{0 i}} \frac{p_{t i}}{p_{0 i}}\right) .
$$

Jeżeli szerokość nośnika wyrazimy w procentach $\left(\frac{p_{t i}}{p_{0 i}}-1\right) \cdot 100 \%$, otrzymamy procentowy poziom zmiany ceny w stosunku do okresu bazowego. Dodatkowo, znak (+) informuje o wzroście, a (-) o spadku ceny. Na rysunku 5. widzimy wykresy z rysunku 4. (po lewej stronie) uzupełnione o wykresy obrazujące dynamikę zmiany ceny (po prawej stronie).

RYSUNEK 4.

Skierowana liczba rozmyta, opisująca cenę $i$-tego dobra w badanym okresie i w okresie bazowym, gdy: a) cena wzrosła, b) cena nie uległa zmianie, c) cena spadła

a)

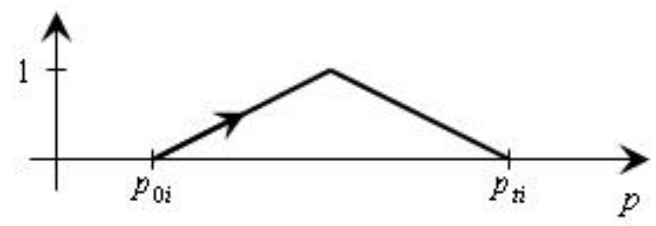

b)

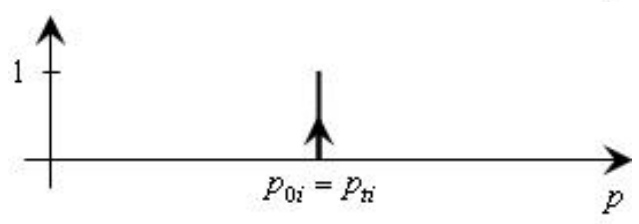

c)

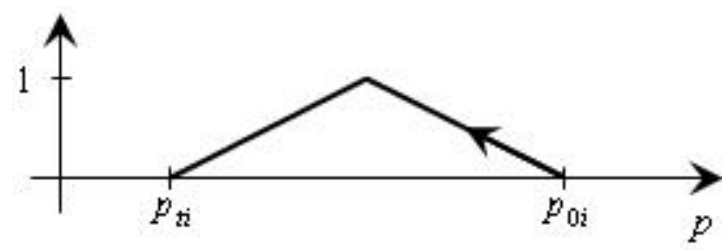

Źródło: opracowanie własne. 
RYSUNEK 5.

Skierowane liczby rozmyte, opisujące cenę $i$-tego dobra w badanym okresie i w okresie bazowym oraz dynamikę zmiany ceny, gdy: a) cena wzrosła, b) cena nie uległa zmianie, c) cena spadła

a)

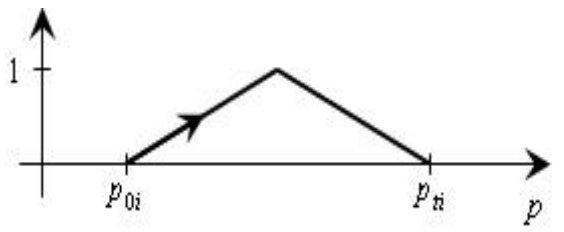

b)

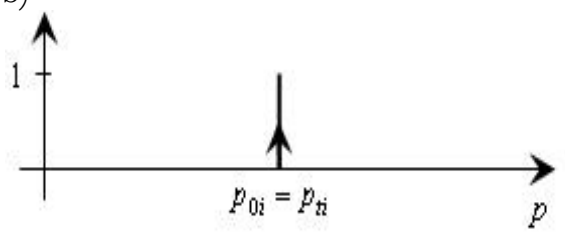

c)

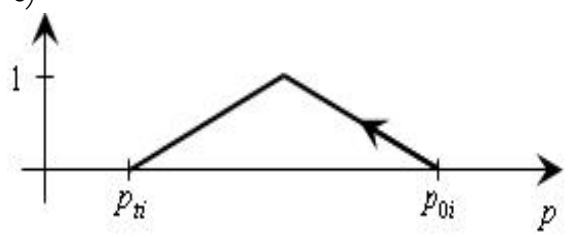

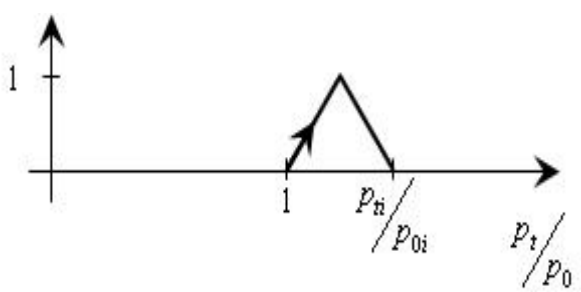
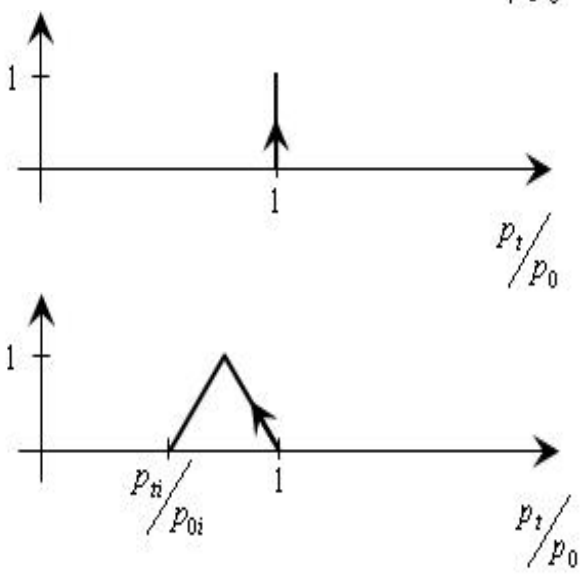

Źródło: opracowanie własne.

Na rysunku 5. każda para wykresów obrazuje ten sam kierunek zmiany ceny. Dodatkowo, wykres cen (po lewej stronie) pokazuje wielkość zmiany ceny wyrażoną w jednostkach pieniężnych, natomiast wykres dynamiki zmiany ceny (po prawej stronie) prezentuje procentowa zmianę ceny mierzoną szerokością nośnika. To właśnie dynamika zmian cen może być kluczowa w procesie decyzyjnym konsumenta. Wykresy po prawej stronie na rysunku 5. pozwalają szybko ocenić i uporządkować dobra od tego, którego cena zmieniła się najbardziej niekorzystnie dla konsumenta (cena wzrosła w największym stopniu) do tego, którego cena zmalała w stopniu największym. Aby to zadanie ułatwić, możemy dynamiki zmian cen wszystkich dóbr przedstawić na jednym wykresie.

Zapisanie informacji o cenach (równanie 6.) oraz dynamice ich zmian (równanie 7.) za pomoca $O F N$ i prezentacja graficzna tych informacji (rysunki: 4. i 5.) pozwalaja łatwo i szybko ocenić, jak zmieniają się ceny pojedynczych dóbr. Jednak ze względu na dużą ilość towarów oraz fakt, że ceny pewnej grupy dóbr wzrastają innej nie ulegaja zmianie, a reszty spadaja, trudno ocenić ich wypadkowy wpływ na wartość i dynamikę zmiany wartości koszyka konsumenta. OFN w łatwy sposób umożliwiaja agregację informacji dla pewnej grupy towarów czy też dla całego koszyka.

Niech wektor $q=\left(q_{1}, q_{2}, \ldots, q_{N}\right)$ opisuje skład koszyka konsumenta, gdzie $q_{i} \in R(i=1,2, \ldots, N)$ są ilościami jednostek $i$-tego dobra w koszyku. W analogiczny 
sposób możemy opisać wektor cen, czyli $p=\left(p_{1}, p_{2}, \ldots, p_{N}\right)$, gdzie $p_{i}(i=$ $1,2, \ldots, N)$ są skierowanymi liczbami rozmytymi, opartymi na cenie bazowej i bieżącej (równanie 6.). Wówczas iloczyn skalarny wektorów $p$ i $q$ :

$$
P=p \circ q=p_{1} \cdot q_{1}+p_{2} \cdot q_{2}+\cdots+p_{N} \cdot q_{N}
$$

opisuje wartość koszyka konsumenta o składzie $q$ przy wektorze cen $p$ [OstojaOstaszewski, 2006]. W reprezentacji skierowanej liczby rozmytej wartość koszyka zapisujemy w postaci:

$$
P=\left(\sum_{i=1}^{N} p_{0 i} q_{i} \sum_{i=1}^{N} \frac{p_{0 i}+p_{t i}}{2} q_{i} \sum_{i=1}^{N} \frac{p_{0 i}+p_{t i}}{2} q_{i} \sum_{i=1}^{N} p_{t i} q_{i}\right),
$$

a ilustracja graficzna jest pokazana na rysunku 6 . Widzimy na nim sytuację, w której wartość koszyka w bieżącym okresie wzrosła w odniesieniu do okresu bazowego.

RYSUNEK 6. Skierowana liczba rozmyta, opisująca wartość koszyka konsumenta w badanym okresie i w okresie bazowym

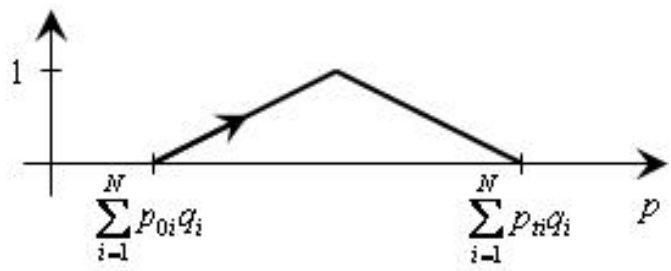

Źródło: opracowanie własne.

Do opisu dynamiki zmiany wartości koszyka konsumenta użyjemy indeksu cen Laspeyresa [óźwiak, Podgórski, 1998]:

$$
\begin{aligned}
& \frac{\sum_{i=1}^{N} p_{t i} q_{i}}{\sum_{i=1}^{N} p_{0 i} q_{i}}=\frac{p_{t 1} q_{1}}{\sum_{i=1}^{N} p_{0 i} q_{i}}+\frac{p_{t 2} q_{2}}{\sum_{i=1}^{N} p_{0 i} q_{i}}+\cdots+\frac{p_{t N} q_{N}}{\sum_{i=1}^{N} p_{0 i} q_{i}}= \\
& =\frac{p_{t 1}}{p_{01}} \cdot \frac{p_{01} q_{1}}{\sum_{i=1}^{N} p_{0 i} q_{i}}+\frac{p_{t 2}}{p_{02}} \cdot \frac{p_{02} q_{2}}{\sum_{i=1}^{N} p_{0 i} q_{i}}+\cdots+\frac{p_{t N}}{p_{0 N}} \cdot \frac{p_{0 N} q_{N}}{\sum_{i=1}^{N} p_{0 i} q_{i}}= \\
& =\frac{p_{t 1}}{p_{01}} \cdot w_{1}+\frac{p_{t 2}}{p_{02}} \cdot w_{2}+\cdots+\frac{p_{t N}}{p_{0 N}} \cdot w_{N},
\end{aligned}
$$

gdzie $w_{i}=\frac{p_{0 i} q_{i}}{\sum_{i=1}^{N} p_{0 i} q_{i}}\left(\sum_{i=1}^{N} w_{i}=1\right)$ są wagami. W konsekwencji, dynamika zmiany wartości koszyka jest średnią ważoną dynamik zmian cen poszczególnych dóbr wchodzących w jego skład z wagami, które określają udziały wydatków na dane dobro w całej sumie wydatków konsumpcyjnych. W reprezentacji skierowanych liczb rozmytych dynamikę zmiany wartości koszyka możemy wyrazić w postaci:

$$
\begin{gathered}
P P=p p_{1} \cdot w_{1}+p p_{2} \cdot w_{2}+\cdots+p p_{N} \cdot w_{N}= \\
=\left(1 \sum_{i=1}^{N} \frac{p_{0 i}+p_{t i}}{2 p_{0 i}} w_{i} \sum_{i=1}^{N} \frac{p_{0 i}+p_{t i}}{2 p_{0 i}} w_{i} \sum_{i=1}^{N} \frac{p_{t i}}{p_{0 i}} w_{i}\right) .
\end{gathered}
$$

Ilustrację graficzną wartości koszyka oraz dynamikę jej zmiany pokazano na rysunku 7. Przedstawia ona sytuację wzrostu wartości koszyka w bieżącym okresie w odniesieniu do okresu bazowego. 
RYSUNEK 7.

Skierowane liczby rozmyte, opisujące zmianę wartości koszyka oraz dynamikę zmiany tej wartości
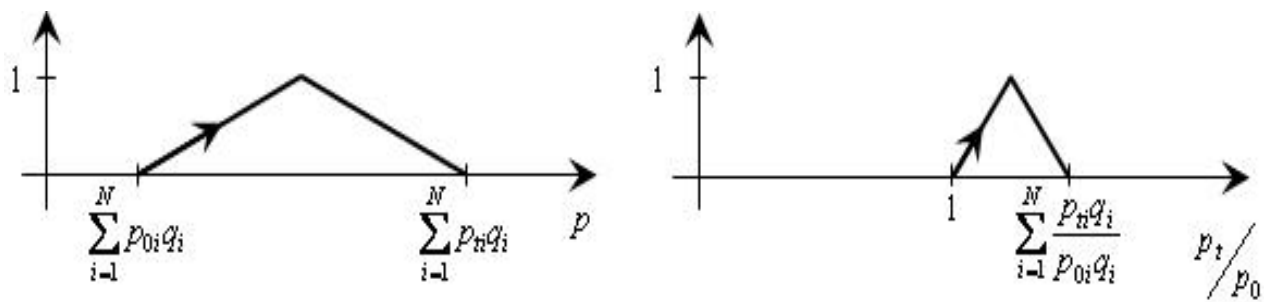

Źródło: opracowanie własne.

Aby bardziej przybliżyć możliwości OFN, rozważmy przykład koszyka dóbr składającego się z trzech towarów: $D 1, D 2$ i $D 3$. Ilości dóbr w koszyku są następujące: $q_{1}=200, q_{2}=300, q_{3}=100$. Ceny tych dóbr, wyrażone w jednostkach pieniężnych w okresie bazowym $(t=0)$ i w okresie bieżącym $(t)$, zestawiono w tabeli 1 . Ceny dóbr: $D 1, D 2$ i $D 3$ zapisane w postaci skierowanych liczb rozmytych (równanie 6.) i skierowane liczby rozmyte, opisujące dynamikę zmian cen (równanie 7.) zestawiono w tabeli 2 .

TABELA 1.

Ceny dóbr: D1, D2 i D3 w okresie bazowym $(t=0)$ oraz w okresie bieżą$\operatorname{cym}(t)$

\begin{tabular}{|c|c|c|}
\hline & $\boldsymbol{t}=\mathbf{0}$ & $\boldsymbol{t}$ \\
\hline $\boldsymbol{D 1}$ & 2 & 3 \\
\hline $\boldsymbol{D 2}$ & 5 & 4 \\
\hline$D 3$ & 20 & 24 \\
\hline
\end{tabular}

Źródło: opracowanie własne.

TABELA 2.

Ceny oraz dynamika zmian cen dóbr: $D 1, D 2$ i $D 3$ zapisane w postaci $O F N$

\begin{tabular}{|l|l|l|}
\hline & \multicolumn{1}{|c|}{ Ceny } & \multicolumn{1}{c|}{ Dynamika } \\
\hline D1 & $p_{1}=(22,52,53)$ & $p p_{1}=(11,251,251,5)$ \\
\hline D2 & $p_{2}=(54,54,54)$ & $p p_{2}=(10,90,90,8)$ \\
\hline D3 & $p_{3}=(20222224)$ & $p p_{3}=(11,11,11,2)$ \\
\hline
\end{tabular}

Źródło: opracowanie własne.

Informacje o cenach i dynamice ich zmian w formie graficznej zobrazowano na rysunku 8. Z wykresów 8 a możemy wywnioskować, że cena dobra $D 1$ wzrosła z po- 
ziomu 2 j.p. do poziomu 3 j.p., co stanowi 50-procentowy wzrost ceny. Z kolei, wykresy 8 b pokazuja, że cena dobra $D 2$ spadła z poziomu 5 j.p. o jedną jednostkę, co stanowi obniżenie ceny o $20 \%$. Natomiast wykresy 8 c ilustrują wzrost ceny dobra $D 3$ z poziomu 20 j.p. o 4 j.p., co oznacza wzrost ceny o $20 \%$.

Aby lepiej ocenić i porównywać zmiany cen, informacje o dynamice ich zmian możemy zestawić na jednym wykresie. Sytuację tę obrazuje rysunek 9. Widzimy dokładnie ceny, których dobra zmalały, których wzrosły oraz jaki jest poziom tej zmiany. Pozwala to konsumentowi uszeregować dobra po względem „dotkliwości” zmiany ceny. Na podstawie rysunku 9. od razu widać, że ceny dóbr: D1 i D3 wzrosły. Ponadto, dynamika zmiany ceny dobra $D 1$ (mierzona szerokością nośnika) jest większa niż dobra $D 3$. Oznacza to dla konsumenta bardziej niekorzystną zmianę ceny dobra $D 1$ niż dobra $D 3$. Następnie cena dobra $D 2$ spadła, czyli zmieniła się najkorzystniej dla konsumenta.

Rozważmy teraz cały koszyk dóbr. Jego wartość można opisać skierowaną liczba rozmytą postaci (równanie 9):

$$
P=p_{1} q_{1}+p_{2} q_{2}+p_{3} q_{3}=(3900405040504200),
$$

którą przedstawiono na rysunku 10.

RYSUNEK 8.

Skierowane liczby rozmyte, opisujące ceny w badanym okresie $\mathrm{i}$ w okresie bazowym oraz dynamikę zmian cen dóbr: a) D1, b) D2, c) D3

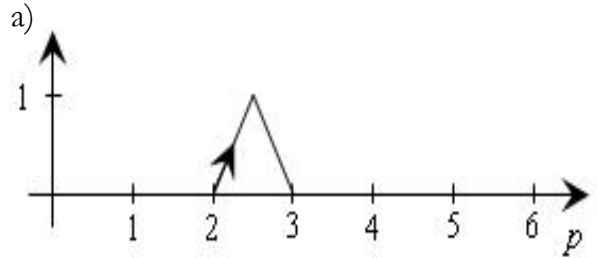

b)

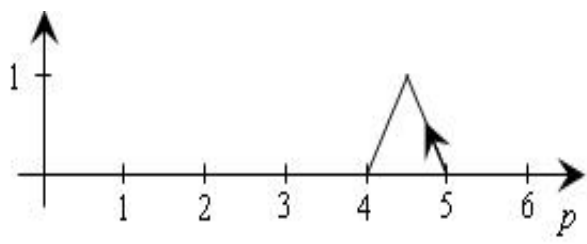

c)

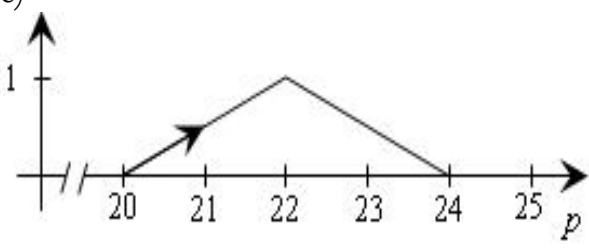

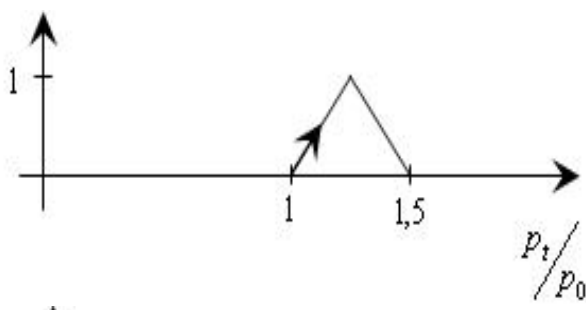
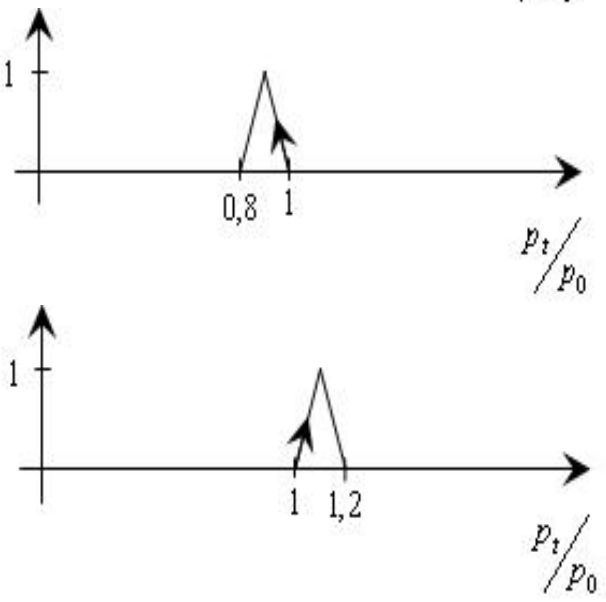

Źródło: opracowanie własne. 
RYSUNEK 9.

Skierowane liczby rozmyte, opisujące dynamikę zmian cen dóbr: D1, D2 i D3

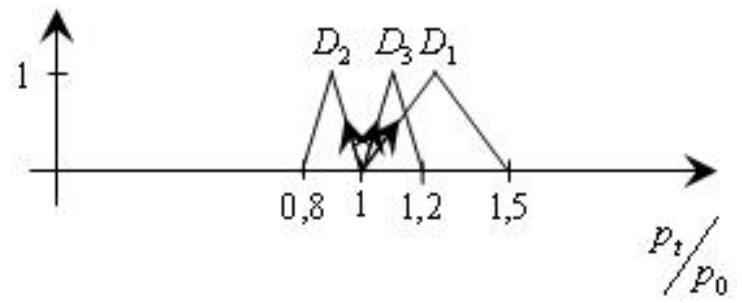

Źródło: opracowanie własne.

RYSUNEK 10.

Skierowana liczba rozmyta, opisująca wartość koszyka dóbr: D1, D2 i D3

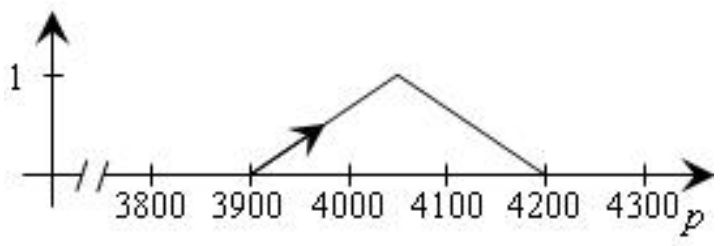

Źródło: opracowanie własne.

Z postaci skierowanej liczby rozmytej $P$ oraz rysunku 10 . wynika, że wartość koszyka dóbr wzrosła o 300 j.p. Aby określić dynamikę zmiany wartości koszyka, wykorzystamy równanie 11 . Wyznaczone wagi są następujące:

$$
w_{1}=\frac{4}{39}, w_{2}=\frac{15}{39}, w_{3}=\frac{20}{39} \text {. }
$$

$\mathrm{Na}$ rysunku 11. pokazano skierowane liczby rozmyte, opisujące dynamiki zmian cen dóbr: $D 1, D 2$ i $D 3$ oraz wagi określające udziały poszczególnych dóbr w koszyku. Umożliwia to wstępne ustalenie, które ceny zmieniły się w jakim kierunku i w jakim stopniu. Ponadto, wagi pozwalają określić, które dobra mają największy wpływ na wartość koszyka. Cena bieżąca dobra $D 1$ wzrosła w największym stopniu w stosunku do ceny w okresie bazowym, ale jego udział w koszyku w stosunku do pozostałych dóbr jest mały (najniższa wartość wagi $w_{1}$ ). Z kolei, największy udział w koszyku ma dobro $D 3$, którego cena wzrosła w takim samym stopniu, w jakim obniżyła się cena dobra D2. Służy to wyciąnnięciu wstępnego wniosku, że wartość koszyka wzrośnie. Aby wyznaczyć precyzyjnie wielkość tego wzrostu, posłużymy się dynamiką zmiany wartości koszyka. Dynamiki zmian cen poszczególnych dóbr i wagi określające udział tych dóbr w koszyku pozwalają ustalić zagregowaną dynamikę zmiany wartości koszyka. Zapisujemy ja w postaci skierowanej liczby rozmytej (równanie 11.):

$$
P P=p p_{1} \cdot w_{1}+p p_{2} \cdot w_{2}+p p_{3} \cdot w_{3}=(11,03851,03851,0769) .
$$


RYSUNEK 11.

Skierowane liczby rozmyte, opisujące dynamikę cen dóbr: D1, D2 i D3 oraz wagi określające udziały poszczególnych dóbr w koszyku

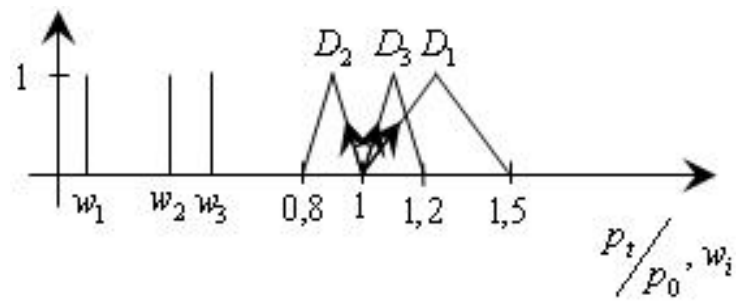

Źródło: opracowanie własne.

RYSUNEK 12.

Skierowana liczba rozmyta, opisująca wartość koszyka dóbr: D1, D2 i D3 oraz liczba rozmyta, opisująca dynamikę zmiany tej wartości
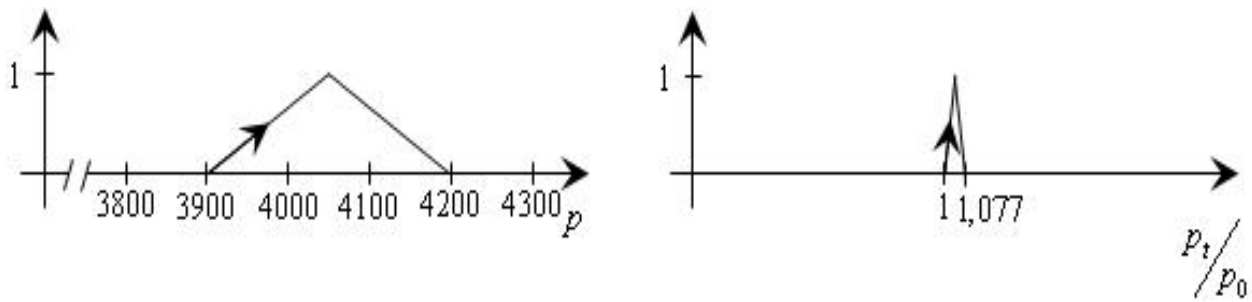

Źródło: opracowanie własne.

Rysunek 12. przedstawia skierowaną liczbę rozmyta, opisująca cenę koszyka dóbr: $D 1, D 2$ i $D 3$ (wykres po lewej stronie) w okresie bazowym oraz badanym. Natomiast wykres po prawej stronie obrazuje dynamikę zmiany wartości koszyka. Wynika z nich, że cena koszyka dóbr: D1, D2 i D3 wzrosła z poziomu 3900 j.p. do poziomu 4200 j.p., co stanowi wzrost wartości koszyka o 7,7\%.

\section{Podsumowanie}

W pracy zaprezentowano model skierowanych liczb rozmytych $(O F N)$, który następnie wykorzystano do opisu i prezentacji cen dóbr konsumpcyjnych, a także dynamiki zmian tych cen. OFN pozwalaja łatwo i szybko agregować informacje o cenach dóbr oraz dynamice ich zmian w trakcie budowy koszyka dóbr. Ponadto, graficzne przedstawienie skierowanych liczb rozmytych umożliwia błyskawiczne odczytanie kilku informacji, jak również uporząakowanie dóbr względem określonego kryterium (np. dynamiki zmiany ceny). 
Zaprezentowany przykład modelu koszyka dóbr jest podobny dla modelu portfela instrumentów finansowych. Oczekiwaną stopę zwrotu portfela wyznacza się analogicznie, jak dynamikę zmiany wartości koszyka. Dalsze badania będa koncentrowały się na próbie wykorzystania skierowanych liczb rozmytych do budowy i opisu portfela papierów wartościowych.

\section{Literatura}

Jóźwiak J., Podgórski J. 1998 Statystyka od podstaw, Polskie Wydawnictwo Ekonomiczne, Warszawa.

Kacprzak D. 2010 Skierowane liczby rozmyte w modelowaniu ekonomicznych, „Optimum. Studia Ekonomiczne", nr 3.

Kacprzak D. 2012a Praychód $i$ koszt catkowity przedsiębiorstwa wyrażony pray użyciu skierowanych licz̧ rozmytych, „Zarządzanie i Finanse”, vol. 10, nr 2, cz. 1.

Kacprzak D. 2012b Zastosowanie skierowanych liçb rozmytych do prezentacii cen akcij, „Optimum. Studia Ekonomiczne”, nr 6.

Kosiński W., Prokopowicz P., Ślęzak D. 2002a Drawback of fuz:y arithmetics - new intutions and propositions, [in:] Methods of Aritificial Intelligence, T. Burczyński, W. Cholewa, W. Moczulski (eds.), Silesian Technical University, Gliwice.

Kosiński W., Prokopowicz P., Ślęzak D. 2002b On algebraic operations on fuz:y reals, [in:] Advances in Soft Computing. Proceedings of the Sixth International Conference on Neutral Networks and Soft Computing, L. Rutkowski, J. Kasprzyk (ed.), Zakopane.

Kosiński W., Prokopowicz P., Ślęzak D. 2003 Ordered fu₹:yy numbers, „Bulletin of the Polish Academy of Sciences Mathematics", vol. 52, no. 3.

Kosiński W., Prokopowicz P. 2004 Algebra lič̨b rozmytych, „Matematyka stosowana”, vol. $5, \mathrm{nr} 46$.

Kosiński W., Prokopowicz P., Kacprzak D. 2009 Fuzziness - representation of dynamic changes by ordered fuz:y number, [in:] Studies In Fuzziness and Soft Computing, R. Seising (ed.), vol. 243.

Ostoja-Ostaszewski A. 2006 Matematyka w ekonomii 1. Modele i metody, Wydawnictwo Naukowe PWN, Warszawa. 